\title{
Effects of Nitrogen and Boron on the Yield and Hollow Stem Disorder of Broccoli (Brassica oleracea var. italica)
}

\author{
M. J. Hussain ${ }^{1,2 *}$, A. J. M. Sirajul Karim², A. R. M. Solaiman² and M. M. Haque ${ }^{3}$ \\ ${ }^{1}$ Bangladesh Agricultural Research Institute, Gazipur-1701, Bangladesh. \\ ${ }^{2}$ Dept. of Soil Science \& ${ }^{3}$ Dept. of Agronomy, Bangabandhu Sheikh Mujibur Rahman Agricultural \\ University, Gazipur-1706, Bangladesh. \\ * Corresponding author and Email: hussainmdjamal@ymail.com
}

Received: 11 April $2012 \quad$ Accepted: 15 November 2012

\begin{abstract}
A field experiment was conducted at the Bangabandhu Sheikh Mujibur Rahman Agricultural University, Gazipur, Bangladesh during winter season, 2007 - 2008 to determine the effects of N and B on the yield and hollow stem disorder of broccoli. Four levels of $\mathrm{N}$ as $0,60,120,180 \mathrm{~kg} \mathrm{ha}^{-1}$ and four levels of $\mathrm{B}$ as $0,0.5,1.0$ and $1.5 \mathrm{~kg} \mathrm{ha}^{-1}$ constituting sixteen treatments were applied in a split plot design with three replications. Applied N and B had significant impact on the yield and hollow stem disorder of broccoli. The highest curd yield of $15.14 \mathrm{t} \mathrm{ha}^{-1}$ was obtained by $180 \mathrm{~kg} \mathrm{~N} \mathrm{ha}^{-1}$. The incidence of hollow stem disorder was increased by increasing rate of $\mathrm{N}$ application and the highest value of hollow stem index of 1.38 was found with $180 \mathrm{~kg} \mathrm{~N} \mathrm{ha}^{-1}$. The curd yield of broccoli was significantly increased with boron application up to $1.0 \mathrm{~kg} \mathrm{ha}^{-1}$. This rate thus showed a remarkable impact on reduction of hollow stem disorder. A moderately high amount of B application $\left(1.0 \mathrm{~kg} \mathrm{ha}^{-1}\right)$ led to minimum incidence of hollow stem disorder, attaining considerably lowest value of hollow stem index of 1.0 as against the maximum value of 1.16 under no application of B. The interaction effect of $\mathrm{N}$ and $\mathrm{B}$ on yield and quality of broccoli was significant and the highest yield $\left(16.68 \mathrm{t} \mathrm{ha}^{-1}\right)$ was recorded under $180 \mathrm{~kg} \mathrm{~N}$ and $1.0 \mathrm{~kg} \mathrm{~B} \mathrm{ha}^{-1}$, which might be recommended for farmer's practice in the Shallow-Red-Brown Terrace Soil of Madhupur Tract.
\end{abstract}

\section{Keywords: Nitrogen, boron, hollow stem disorder, broccoli}

\section{Introduction}

Broccoli (Brassica oleracea var. italica L.) is an important vitamin rich winter vegetable. It is a member of Cole crops, which is newly introduced in Bangladesh. It is fairly rich in carotene and ascorbic acid and contains appreciable quantities of thiamin, riboflavin, niacin and iron (Thompson and Kelly, 1985). Successful production of broccoli depends on various factors of which fertilizer application is the most important one.
Hollow stem disorder is a major problem in broccoli production which is responsible for yield reduction and is commonly associated with B deficiency (Shelp et al., 1992) as well as higher nitrogen rates (Babik and Elkner, 1999). The incidence of hollow stem was increased by increasing application of nitrogen fertilizer (Hipp, 1974). Boron deficiency causes many anatomical, physiological and biochemical changes. Sartori and Mello (2009) reported a negative correlation between $\mathrm{B}$ concentration in leaves and curds with hollow stem disorder. It 
was reported by Lent and Scarchuk (1954) that stem hollowing in the Brassicas had long been associated with B deficiency.

According to Bradford (1975), boron deficiency is associated with hollow stem disorder in cauliflower, where nitrogen application at higher rates is known to aggravate the problem. Similar observations were reported by Moniruzzaman et al. (2007) for broccoli. Broccoli cultivar Premium Crop is susceptible to boron deficiency as well as hollow stem disorder. Therefore, nitrogen and boron management is a crucial factor for yield and quality as well as to control hollow stem disorder of broccoli. The study was undertaken to determine the role of $\mathrm{N}$ and $\mathrm{B}$ on yield and hollow stem disorder of broccoli and to determine the optimum doses of $\mathrm{N}$ and $\mathrm{B}$ for broccoli production as well as to control hollow stem disorder.

\section{Materials and Methods}

The experiment was conducted at the research farm of Bangabandhu Sheikh Muzibur Rahman Agricultural University (BSMRAU), Gazipur, Bangladesh, during November 17, 2007 to February 13, 2008. The soil of the experimental site was silty clay loam in texture having the bulk density $1.40 \mathrm{~g} \mathrm{~cm}^{-3}$ which belongs to Salna series of Shallow Red-Brown Terrace Soil under Agro-Ecological Zone Madhupur Tract (AEZ 28). Some chemical properties of the soil are presented in Table 1. The Experiment was carried out in a split-plot design with three replications. Four levels of nitrogen i) $0 \mathrm{~kg} \mathrm{~N}$ $\mathrm{ha}^{-1}$, ii) $60 \mathrm{~kg} \mathrm{~N} \mathrm{ha}^{-1}$, iii) $120 \mathrm{~kg} \mathrm{~N} \mathrm{ha}^{-1}$ and iv) $180 \mathrm{~kg} \mathrm{~N} \mathrm{ha}^{-1}$ were assigned in the main plots and four levels of boron i) $0 \mathrm{~kg} \mathrm{~B} \mathrm{ha}^{-1}$, ii) $0.5 \mathrm{~kg}$ $\mathrm{B} \mathrm{ha}^{-1}$, iii) $1.0 \mathrm{~kg} \mathrm{~B} \mathrm{ha}^{-1}$ and iv) $1.5 \mathrm{~kg} \mathrm{~B} \mathrm{ha}^{-1}$ were assigned with subplots. The row to row and plant to plant distance was 60 and $45 \mathrm{~cm}$, respectively. All other fertilizers were applied uniformly as a blanket dose for all treatment at the rate of $53 \mathrm{~kg} \mathrm{P}, 83 \mathrm{~kg} \mathrm{~K}, 20 \mathrm{~kg} \mathrm{~S}, 2.0 \mathrm{~kg} \mathrm{Zn}$ and $0.8 \mathrm{~kg} \mathrm{Mo} \mathrm{ha}^{-1}$. Twenty five day-old healthy broccoli (var. italica L. cv. Premium Crop) seedlings were transplanted in the experimental plot on November 17. All the fertilizers except urea and MOP were applied as basal and were incorporated into the soil during final land preparation. Urea and MOP were applied in two equal splits at $15 \mathrm{DAT}$ and 30 DAT followed by ring method around the plant bases. At an early stage, sprinkler irrigation was applied and at later stages irrigation water was applied in the furrows at an interval of 7 days. Necessary intercultural operations and weeding were done properly. Crop harvesting was started on $17^{\text {th }}$ January and continued up to $28^{\text {th }}$ January.

Table 1. Some chemical properties of the soil of experimental site

\begin{tabular}{lc}
\hline Chemical properties & Analytical results \\
\hline Soil $\mathrm{pH}$ & 6.4 \\
Total $\mathrm{N}(\%)$ & 0.11 \\
Organic carbon $(\%)$ & 1.146 \\
$\mathrm{C}: \mathrm{N}$ ratio & 10.42 \\
Boron $(\mu \mathrm{g} / \mathrm{g}$ soil) & 0.455 \\
Available P $(\mu \mathrm{g} / \mathrm{g}$ soil) & 25.583 \\
Exchangeable K (meq/100g soil) & 0.363 \\
Available S $((\mu \mathrm{g} / \mathrm{g}$ soil) $)$ & 44.32 \\
Total Zn $(\mu \mathrm{g} / \mathrm{g}$ soil) & 3.25 \\
Exchangeable Ca (meq/100g soil) & 7.448 \\
Exchangeable Mg (meq/100g soil) & 2.21 \\
CEC (meq/100g soil) & 11.908 \\
\hline
\end{tabular}


Data on different plant parameters were recorded from 10 randomly selected plants located at the middle of each plot leaving adequate border plants. Similar number of plants and curds were observed for determination of yield and hollow stem disorder. The crop was harvested when the curd/inflorescence attained at commercial maturity (13-15 cm in diameter and just started to swell but before opening the flower bud). The weight of individual curd was taken including the stalk with three young leaves and the marketable portion of the plant was considered to the extent of about $15 \mathrm{~cm}$ from the top of the inflorescence along the stem (Liu et al., 1993). Hollow stem index (HI) was determined by the methodology followed by Shattuck and Shelp (1987) and was rated through visual inspection of longitudinal section of the stalk and head. Accordingly, the incidence of hollow stem was observed at the stem base of heads, $15-18 \mathrm{~cm}$ in length according to Shattuck et al. (1986) and was expressed as hollow stem index (HI) as stated by Shattuck and Shelp (1987). Each longitudinal head section was scored according to the following scale:

$$
\begin{aligned}
& 0=\text { hollow stem absent } \\
& 1=\text { slight hollow stem } \\
& 2=\text { moderate hollow stem } \\
& 3=\text { severe hollow stem }
\end{aligned}
$$

The hollow stem index (HI) for each replication was calculated using the following equation:

$$
\begin{aligned}
& \mathrm{HI}=\sum \mathrm{n}_{\mathrm{i}} \mathrm{X}_{\mathrm{i}} / \mathrm{N} \\
& \quad \mathrm{i}=0 \\
& \text { Where, } \\
& \mathrm{n}_{\mathrm{i}}=\text { number of plants in the ith scale class } \\
& \mathrm{X}_{\mathrm{i}}=\text { the ith scale value and } \\
& \mathrm{N}=\text { total number of plants scored. }
\end{aligned}
$$

The highest index indicates the most severe case of hollow stem disorder and the lowest indicates the least hollow stem disorder. Data were analyzed statistically through partitioning the total variance into different sources of variation using a computer program "MSTATC". The values of hollow stem index were converted to a degree by squire root transformation prior to analysis to bring homogeneity and additivity.
The treatment comparison was made followed by Duncan's Multiple Range Test (DMRT) at 5\% $(\mathrm{p} \leq 0.05)$ level of significance. Correlation coefficient and regression analysis were done using Microsoft Excel program.

\section{Results and Discussion}

\subsection{Effects of $N$ and $B$ on different plant parameters}

\subsubsection{Plant height}

A significant effect of $\mathrm{N}$ on plant height was found as a main plot effect (Table 2). At commercial maturity, plant height was significantly influenced by different $\mathrm{N}$ and $\mathrm{B}$ levels. It was increased with the increasing rate of $\mathrm{N}$ application and the tallest plant $(70.68 \mathrm{~cm})$ was recorded under $180 \mathrm{~kg} \mathrm{~N} \mathrm{ha}^{-1}$ followed by $120 \mathrm{~kg} \mathrm{ha}^{-1}$. Minimum plant height was found from the treatment, which received no $\mathrm{N}$ fertilizer. Nitrogen application at the rate of 60 , 120 and $180 \mathrm{~kg} \mathrm{ha}^{-1}$ in presence of other elements showed 20.6, 23.3 and 28.6\% higher plant height over control treatment, respectively. Higher amount of nitrogen application led to better vegetative growth of plants to attain the highest plant height. This result is supported by Nasreen and Islam (1992) and Moniruzzaman et al. (2007). The main effect of B on plant height was also found significant (Table 2). In that case, plant height was significantly influenced by the different levels of $\mathrm{B}$ and it was gradually increased up to $1.0 \mathrm{~kg} \mathrm{~B} \mathrm{ha}^{-1}$ and then it was decreased. The highest plant height $(65.72 \mathrm{~cm})$ was noted from the treatment receiving $B$ at 1.0 $\mathrm{kg} \mathrm{ha}^{-1}$ which was statistically similar to 0.5 and $1.5 \mathrm{~kg} \mathrm{~B} \mathrm{ha}{ }^{-1}$. The lowest plant height $(58.00 \mathrm{~cm})$ was found under no application of B. Sharma and Arora (1984) reported the maximum plant height found $2.5 \mathrm{~kg} \mathrm{~B} \mathrm{ha}^{-1}$ in cauliflower. The interaction effects of $\mathrm{N}$ and $\mathrm{B}$ on plant height was found insignificant.

\subsubsection{Stem diameter}

The cultivar used in the experiment had susceptibility to hollow stem disorder. The stem 
diameter in this cultivar varied with the variation of top growth. Like other yield components of broccoli mentioned earlier, the diameter of the stem varied significantly with different levels of $\mathrm{N}$ fertilizer. The stem diameter was increased with the increasing rate of $\mathrm{N}$ (Table 2) and the highest diameter $(5.83 \mathrm{~cm})$ was recorded from $180 \mathrm{~kg} \mathrm{~N} \mathrm{ha}^{-1}$, achieving the maximum yield $\left(1.38\right.$ ton $^{-1}$ ) and it was statistically identical to $120 \mathrm{~kg} \mathrm{~N} \mathrm{ha}^{-1}$. However, it was increased with increasing rate of $\mathrm{B}$ up to $1.0 \mathrm{~kg} \mathrm{ha}^{-1}$ and then was decreased (Table 2). The higher dose of $\mathrm{B}$ $\left(1.0 \mathrm{~kg} \mathrm{ha}^{-1}\right)$ produced the highest stem diameter $(5.32 \mathrm{~cm})$ which was statistically similar to that obtained from B level of $1.5 \mathrm{~kg} \mathrm{ha}^{-1}$. The lowest stem diameter $(4.69 \mathrm{~cm})$ was recorded from B level $0 \mathrm{~kg} \mathrm{ha}^{-1}$. Application of higher levels of B led to an increase in stem diameter of broccoli but it was increased up to a certain limit and then declined. There was no significant interaction effect of $\mathrm{N}$ and $\mathrm{B}$ on stem diameter. These results are in agreement with those reported by Sajeemas et al. (2006).

\subsubsection{Curd diameter}

The shape of the main curd is a genetic character. The cultivar used in the experiment had round head. The curd diameter in this cultivar can be considered as an appropriate measure of curd size. The curd diameter was increased significantly with increasing rate of $\mathrm{N}$ fertilizer (Table 2). The highest dose of N (180 $\mathrm{kg} \mathrm{h} \mathrm{h}^{-1}$ ) produced the highest curd diameter $(15.02 \mathrm{~cm})$ which was statistically similar to those obtained from $120 \mathrm{~kg}$ and $60 \mathrm{~kg} \mathrm{~N} \mathrm{ha}^{-1}$. The lowest curd diameter $(9.15 \mathrm{~cm})$ was recorded from the plot where $\mathrm{N}$ was not applied. The increment of curd diameter was 64.15 and $54.64 \%$ under application of $180 \mathrm{~g}$ and $120 \mathrm{~kg} \mathrm{~N}$ $\mathrm{ha}^{-1}$, respectively as compared to $0 \mathrm{~kg} \mathrm{~N} \mathrm{ha}^{-1}$. This result is very close to that of Thompson and Kelly (1985). Curd diameter was significantly increased by B application but there was no significant variation among $B$ treated plots (Table 2). The highest curd diameter $(15.02 \mathrm{~cm})$ was recorded with $1.5 \mathrm{~kg} \mathrm{~B} \mathrm{ha}^{-1}$ followed by 1.0 $\mathrm{kg} \mathrm{B} \mathrm{ha}{ }^{-1}$, which produced curd diameter of
$14.15 \mathrm{~cm}$. The minimum diameter was found in treatment where no B was added. This result is supported by Sanjoy et al. (2002) as who found that Mo and B application significantly increased curd diameter, weight and yield of cauliflower. The interaction effect of $\mathrm{N}$ and $\mathrm{B}$ on the curd diameter of broccoli was not significant.

\subsubsection{Curd weight}

Individual curd weight was significantly influenced by the different levels of $\mathrm{N}$ and $\mathrm{B}$. Addition of $\mathrm{N}$ had created significant positive impact on individual curd weight and led to significant increase in curd weight (Table 3 ). The highest individual curd weight (416.2 $\left.\mathrm{g} \mathrm{plant}^{-1}\right)$ was recorded at $180 \mathrm{~kg} \mathrm{~N} \mathrm{ha-1}$, which was reduced sequentially with decreased rate of $\mathrm{N}$ application with the lowest value of $115.3 \mathrm{~g}$ plant $^{-1}$ under $0 \mathrm{~kg} \mathrm{~N} \mathrm{ha}^{-1}$. Individual curd weight was also significantly influenced by different levels of B. It was increased with the increased B level up to $1.0 \mathrm{~kg} \mathrm{ha}^{-1}$ and was then declined (Table 3). The highest curd weight (281.7 g plant $^{-1}$ ) was obtained from the B level $1.0 \mathrm{~kg} \mathrm{ha}$ ${ }^{1}$, which was statistically similar to B level $1.5 \mathrm{~kg}$ $\mathrm{ha}^{-1}\left(274.4 \mathrm{~g} \mathrm{plant}^{-1}\right)$ but was different from 0.5 and $0 \mathrm{~kg} \mathrm{~B} \mathrm{ha}{ }^{-1}$. The minimum curd weight (222.2 $\mathrm{g} \mathrm{plant}^{-1}$ ) was recorded from $0 \mathrm{~kg} \mathrm{~B} \mathrm{ha}^{-1}$. Boron application at the rate of 1.0, 1.5 and 0.5 $\mathrm{kg} \mathrm{ha}^{-1}$ gave 26.78, 23.49 and $11.34 \%$ higher curd weight/plant, respectively over B-control. Mishra and Singh (1984) found the similar result in cauliflower.

The interaction effect of $\mathrm{N}$ and $\mathrm{B}$ on the individual curd weight of broccoli was significant (Table 4). The highest curd weight $\left(480.3 \mathrm{~g}\right.$ plant $\left.^{-1}\right)$ was obtained from the combination of $180 \mathrm{~kg} \mathrm{~N} \mathrm{ha}^{-1} \times 1.0 \mathrm{~kg} \mathrm{~B} \mathrm{ha}^{-1}$, which was significantly different from all other treatments, being followed by the combination $180 \mathrm{~kg} \mathrm{~N} \times 0.5 \mathrm{~kg} \mathrm{~B}\left(405.7 \mathrm{~g} \mathrm{plant}^{-1}\right)$. The lowest value $\left(380.5 \mathrm{~g} \mathrm{plant}^{-1}\right)$ was recorded from $180 \mathrm{~kg} \mathrm{~N} \times 0 \mathrm{~kg} \mathrm{~B} \mathrm{ha}^{-1}$. Mishra and Singh (1984) also found the similar effects of $\mathrm{N}$ and $\mathrm{B}$ on this character of cauliflower. 
Table 2. Main effect of $\mathrm{N}$ and $\mathrm{B}$ on different plant parameters of broccoli at commercial maturity

\begin{tabular}{cccc}
\hline Treatment & $\begin{array}{c}\text { Plant height }(\mathrm{cm}) \text { at } \\
\text { maturity }\end{array}$ & Stem diameter $(\mathrm{cm})$ & $\begin{array}{c}\text { Curd diameter } \\
(\mathrm{cm})\end{array}$ \\
\hline N level $\left(\mathrm{kg} \mathrm{ha}^{-1}\right)$ & & & $9.146 \mathrm{c}$ \\
\hline 0 & $54.95 \mathrm{c}$ & $3.896 \mathrm{c}$ & $12.76 \mathrm{~b}$ \\
60 & $66.25 \mathrm{~b}$ & $5.957 \mathrm{~b}$ & $14.15 \mathrm{ab}$ \\
120 & $67.78 \mathrm{~b}$ & $5.738 \mathrm{a}$ & $15.02 \mathrm{a}$ \\
\hline 180 & $70.68 \mathrm{a}$ & $5.833 \mathrm{a}$ & $11.76 \mathrm{~b}$ \\
\hline B level $\left(\mathrm{kg} \mathrm{ha}^{-1}\right)$ & & & $12.70 \mathrm{a}$ \\
0 & $63.50 \mathrm{~b}$ & $4.696 \mathrm{~b}$ & $13.31 \mathrm{a}$ \\
1.0 & $64.95 \mathrm{ab}$ & $5.136 \mathrm{a}$ & $13.32 \mathrm{a}$ \\
\hline CV $(\%)$ & $65.72 \mathrm{a}$ & $5.321 \mathrm{a}$ & 6.29 \\
\hline
\end{tabular}

In column the common letters are not significantly different from each other at $5 \%$ level of significance by DMRT

Table 3. Main effect of $\mathrm{N}$ and $\mathrm{B}$ on Curd yield $(\mathrm{g} / \mathrm{pl})$ of broccoli at commercial maturity

\begin{tabular}{cccc}
\hline \multicolumn{2}{c}{ Main effect of $\mathrm{N}$} & \multicolumn{2}{c}{ Main effect of B } \\
\hline N level $\left(\mathrm{kg} \mathrm{ha}^{-1}\right)$ & Curd yield (g/plant) & B level $\left(\mathrm{kg} \mathrm{ha}^{-1}\right)$ & Curd yield (g/plant) \\
\hline 0 & $115.3 \mathrm{~d}$ & 0 & $222.2 \mathrm{c}$ \\
60 & $181.4 \mathrm{c}$ & 0.5 & $247.4 \mathrm{~b}$ \\
120 & $312.7 \mathrm{~b}$ & 1.0 & $281.7 \mathrm{a}$ \\
180 & $416.2 \mathrm{a}$ & 1.5 & $274.4 \mathrm{a}$ \\
\hline $\mathrm{CV}(\%)$ & 7.69 & $\mathrm{CV}(\%)$ & 7.69
\end{tabular}

In column the common letters are not significantly different from each other at $5 \%$ level of significance by DMRT

Table 4. Interaction effect of $\mathrm{N}$ and $\mathrm{B}$ on curd yield (g/plant) of broccoli

\begin{tabular}{ccccc}
\hline Treatment & \multicolumn{4}{c}{ N level $\left(\mathrm{kg} \mathrm{ha}^{-1}\right)$} \\
\hline B level $\left(\mathrm{kg} \mathrm{ha}^{-1}\right)$ & 0 & 60 & 120 & 180 \\
\hline 0 & $109.90 \mathrm{~g}$ & $141.1 \mathrm{~g}$ & $257.40 \mathrm{e}$ & $380.50 \mathrm{bc}$ \\
0.5 & $116.10 \mathrm{~g}$ & $178.6 \mathrm{f}$ & $289.10 \mathrm{e}$ & $405.70 \mathrm{~b}$ \\
1.0 & $117.20 \mathrm{~g}$ & $193.2 \mathrm{f}$ & $335.90 \mathrm{~d}$ & $480.30 \mathrm{a}$ \\
1.5 & $117.90 \mathrm{~g}$ & $212.90 \mathrm{f}$ & $368.54 \mathrm{~cd}$ & $398.50 \mathrm{bc}$ \\
\hline $\mathrm{CV}(\%)$ & 7.69 & & \\
\hline
\end{tabular}

In column the common letters are not significantly different from each other at $5 \%$ level of significance by DMRT 


\subsubsection{Curd yield}

The response of curd yield of broccoli to applied $\mathrm{N}$ was significant as it was also observed in same of individual curd weight/plant. The curd yield increased significantly with each incremental dose of $\mathrm{N}$. The highest yield of $15.14 \mathrm{t} \mathrm{ha}^{-1}$ was recorded under the highest rate of $\mathrm{N}$ application $\left(180 \mathrm{~kg} \mathrm{ha}^{-1}\right)$, which was significantly different from all other treatments. The rate of increased curd yield of broccoli by application of 180, 120 and $60 \mathrm{~kg} \mathrm{~N}^{-1}$ over the control treatment $(0.0$ $\mathrm{kg} \mathrm{N})$ were 254.57, 171.66 and 59.25\%, respectively. Thus, the indispensability of higher doses of $\mathrm{N}$ application for achieving better yield of broccoli is evident. From the response curve (Fig.1) it was found that the yield was highly correlated with $\mathrm{N}$ level $\left(\mathrm{R}^{2}=0.987\right)$, which indicated that maximum increase in curd yield with the highest $\mathrm{N}$ level of $180 \mathrm{~kg} \mathrm{ha}^{-1}$. Default (1988); Mishra and Singh (1984) and Trimblay (1989) reported similar results. Erdem et al. (2010) also reported that the yield of broccoli (var. Italica) was increased with increasing rate of nitrogen application. Similar results were observed by Moniruzzaman et al. (2007) for broccoli.

Curd yield was also significantly increased by addition B to soil up to $1.0 \mathrm{~kg} \mathrm{ha}^{-1}$ (Fig. 2). The highest curd yield $\left(10.25 \mathrm{t} \mathrm{ha}^{-1}\right)$ was obtained from the $\mathrm{B}$ level of $1.5 \mathrm{~kg} \mathrm{ha}^{-1}$, which was identical to B level of $1.0 \mathrm{~kg} \mathrm{ha}^{-1}\left(10.15 \mathrm{t} \mathrm{ha}^{-1}\right)$. Boron application at the rate of $1.5,1.0$ and 0.5 $\mathrm{kg}$ gave 24.54, 23.37 and $11.54 \%$ higher curd yield, respectively over control. Curd yield was highly correlated with $\mathrm{B}$ level depicting $\mathrm{R}^{2}=$ 0.9168 , which indicated that maximum increase in curd yield by $92 \%$ with the highest B level of $1.5 \mathrm{~kg} \mathrm{ha}^{-1}$. These findings are in agreement with those of Mishra and Singh (1984) who obtained the highest curd yield $\left(21.97 \mathrm{t} \mathrm{ha}^{-1}\right)$ with $1.5 \mathrm{~kg} \mathrm{~B}$ $\mathrm{ha}^{-1}$.

The curd yield of broccoli was significantly influenced by the combined effect of $\mathrm{N}$ and $\mathrm{B}$ application (Table 5). It was revealed that curd yield increased with the increasing rate of $\mathrm{N}$ application but it increased with increasing rate of $\mathrm{B}$ up to $1.0 \mathrm{~kg} \mathrm{~B} \mathrm{ha}^{-1}$ and decreased with further increase of $\mathrm{B}$ application. The highest curd yield $\left(16.68 \mathrm{t} \mathrm{ha}^{-1}\right)$ was obtained from the combined dose of $180 \mathrm{~kg} \mathrm{~N} \mathrm{ha}^{-1} \times 1.0 \mathrm{~kg} \mathrm{~B} \mathrm{ha}^{-1}$, which was significantly different from all other treatment combinations. Mishra and Singh (1984) found the similar interaction effect on this character. This might be due to the higher crop growth with high accumulation and translocation of photosynthetic materials to the curd. From the above discussion, it may be ascertained that the combined dose of $\mathrm{N}$ and $\mathrm{B}$ application at the rate of $180 \mathrm{~kg} \mathrm{~N}$ along with $1.0 \mathrm{~kg} \mathrm{~B} \mathrm{ha}^{-1}$ are the optimum dose to be applied to soil for getting maximum yield of broccoli.

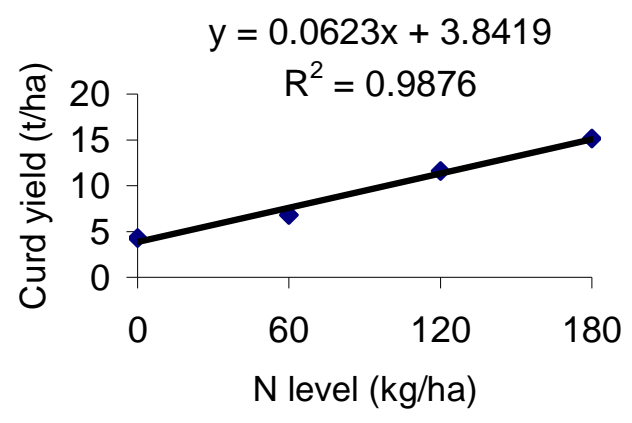

Fig. 1. Effect of different nitrogen levels on curd yield (t/ha) of broccoli 


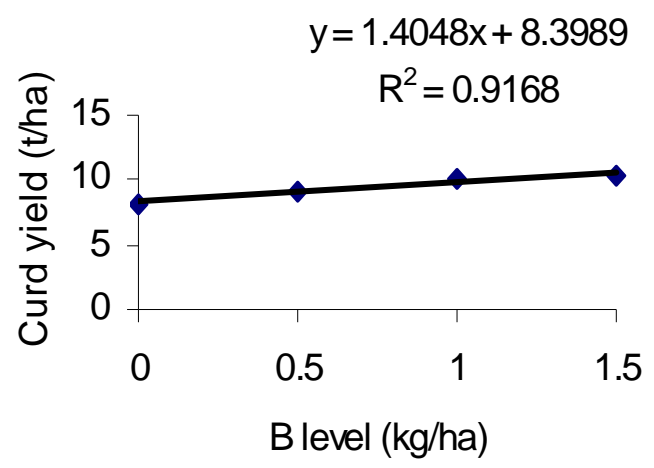

Fig. 2. Effect of different boron levels on curd yield ( $\mathrm{t} / \mathrm{ha}$ ) of broccoli

Table 5. Interaction effect of $\mathrm{N}$ and $\mathrm{B}$ on curd yield (t/ha) of broccoli

\begin{tabular}{ccccc}
\hline Treatment & \multicolumn{4}{c}{$\mathrm{N}$ level $\left(\mathrm{kg} \mathrm{ha}^{-1}\right)$} \\
\hline B level $\left(\mathrm{kg} \mathrm{ha}^{-1}\right)$ & 0 & 60 & 120 & 180 \\
\hline 0 & $4.070 \mathrm{j}$ & $5.227 \mathrm{i}$ & $9.533 \mathrm{f}$ & $14.090 \mathrm{bc}$ \\
0.5 & $4.300 \mathrm{ij}$ & $6.610 \mathrm{~h}$ & $10.780 \mathrm{e}$ & $15.030 \mathrm{~b}$ \\
1.0 & $4.343 \mathrm{ij}$ & $7.153 \mathrm{~h}$ & $12.440 \mathrm{~d}$ & $16.680 \mathrm{a}$ \\
1.5 & $4.367 \mathrm{ij}$ & $8.217 \mathrm{~g}$ & $13.65 \mathrm{c}$ & $14.760 \mathrm{~b}$ \\
\hline CV $(\%)$ & 5.67 & & &
\end{tabular}

In column the common letters are not significantly different from each other at $5 \%$ level of significance by DMRT

\subsection{Effect of $N$ and $B$ on hollow stem index $(\mathrm{HI})$}

The hollow stem index (HI) was significantly influenced by the different levels of $\mathrm{N}$ and $\mathrm{B}$ (Fig. $1 \&$ 2) and their interaction (Table 6). From the data (Table 1) it was revealed that the hollow stem index of broccoli was favored by increasing rate of $\mathrm{N}$ application and the maximum severity of hollow stem disorder (HI-1.39) was noted under the application of $180 \mathrm{~kg} \mathrm{~N} \mathrm{ha}{ }^{-1}$, which was significantly higher than those of any other treatments. The intensity of this disorder decreased significantly with decrease in $\mathrm{N}$ rate and attained to the minimum value of 0.7424 with no application of $\mathrm{N}$. It was revealed that increased rate of $\mathrm{N}$ application increased the vegetative growth of plants and the turgidity of plant cells that might have led to hollowness in the stem. From Fig. 3 it was found that the HI was highly correlated with $\mathrm{N}$ level $\left(\mathrm{R}^{2}=0.9739\right)$, which indicated that maximum increase in $\mathrm{HI}$ by $97 \%$ with the highest $\mathrm{N}$ level of $180 \mathrm{~kg} \mathrm{ha}^{-1}$. This result was supported by that of Trimblay (1989) who stated that increasing $\mathrm{N}$ rate resulted in greater vegetative growth but also in hollower stem development in broccoli.

Hollow stem index was also significantly influenced by different B level. It decreased with the increase in B level up to $1.0 \mathrm{~kg} \mathrm{ha}^{-1}$ and was then increased (Fig. 4). The highest hollow stem index (1.161) was found from the B level $0 \mathrm{~kg}$ 
$\mathrm{ha}^{-1}$, which was significantly different from all other B levels. The minimum hollow stem index (1.003) was noted from the B level $1.0 \mathrm{~kg} \mathrm{ha}^{-1}$. It means that increase of $B$ level up to a certain limit may decrease the hollow stem disorder. From the response curve (Fig. 4), it observed that the $\mathrm{HI}$ was negatively correlated with $\mathrm{B}$ level $\left(\mathrm{R}^{2}\right.$ $=0.0 .9228)$, which indicated that maximum decrease in HI by $92 \%$ with the highest B level of $1.0 \mathrm{~kg}$ ha-1. This result is supported that of Lent and Scarchuk (1954) who mentioned that stem hollowing in the Brassicas had long been associated with B deficiency. Vigier and Cutcliffe (1984) also suggested that a portion of the hollow stem disorder in broccoli could be attributed to $\mathrm{B}$ deficiency. The findings also supported by Shattuck and Shelp (1987) who found that broccoli variety Premium Crop grown in the absence of B showed initial signs of hollow stem which was alleviated by adding B. It was suggested that $B$ nutrition might be involved in the induction of hollow stem in broccoli. Similarly, Moniruzzaman et al. (2007) reported that B deficiency is associated with hollow stem in broccoli.
Interaction effect of $\mathrm{N}$ and $\mathrm{B}$ on the hollow stem index (HI) was also found significant (Table 6). the highest hollow stem index (1.55) was recorded from the combination of $180 \mathrm{~kg} \mathrm{~N} \times 0$ $\mathrm{kg} \mathrm{B}$, followed by $180 \mathrm{~kg} \mathrm{~N} \times 1.5 \mathrm{~kg} \mathrm{~B}$, and 120 $\mathrm{kg} \mathrm{N} \times 0 \mathrm{~kg} \mathrm{~B}$ which were identical to each other. The lowest HI (0.7071) was found from the combination of $0 \mathrm{~kg} \mathrm{~N} \times 0 \mathrm{~kg}$ B. It was revealed that increasing rate of $\mathrm{N}$ also increased the hollow stem index under each B level. It was observed that within $\mathrm{N}$ level of $180 \mathrm{~kg} \mathrm{ha}^{-1}$, hollow stem index decreased up to $1.0 \mathrm{~kg} \mathrm{~B}$ level and then it was increased. The intensity of this disorder decreased significantly with decreased $\mathrm{N}$ rate and reached the minimum value of 0.707 with no application of $\mathrm{N}$ and $\mathrm{B}$. But, increase in $\mathrm{B}$ level up to a certain limit along with higher doses of $\mathrm{N}$, decreased the hollow stem disorder. It was revealed from the observation that increased rate of $\mathrm{N}$ application increased the vegetative growth of plants and the turgidity of plant cells which might have enhanced hollowness in the stem. Both yield and curd quality was reduced due to the presence of hollow stem disorder. However, this could be checked by applying $\mathrm{B}$ at $1.0 \mathrm{~kg} \mathrm{ha} \mathrm{ha}^{-1}$.

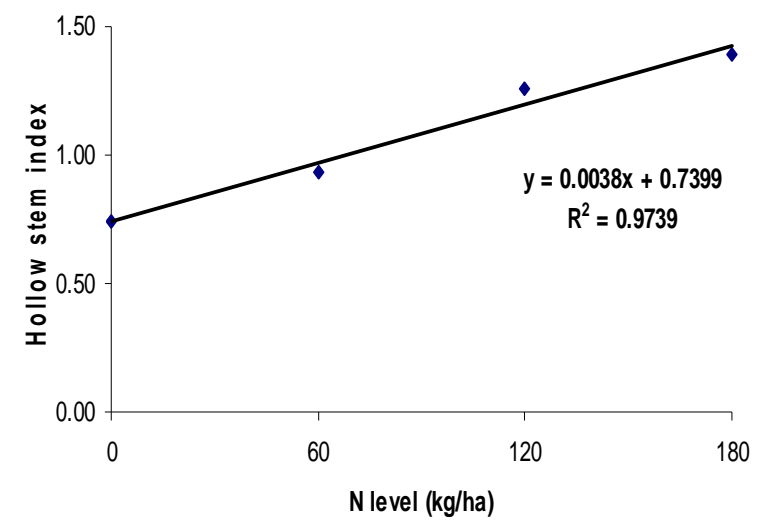

Fig. 3. Quadratic relationship of N on hollow stem index of broccoli 


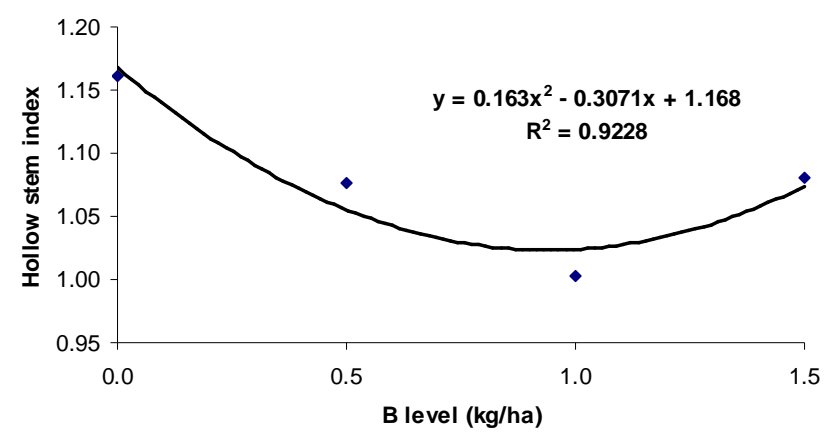

Fig. 4. Effect of different levels of B on hollow stem index of broccoli

Table 6. Interaction effect of $\mathrm{N}$ and $\mathrm{B}$ on hollow stem index (HI) of broccoli at commercial maturity

\begin{tabular}{ccccc}
\hline Treatment & \multicolumn{4}{c}{ N level $\left(\mathrm{kg} \mathrm{ha}^{-1}\right)$} \\
\hline B level $\left(\mathrm{kg} \mathrm{ha}^{-1}\right)$ & 0 & 60 & 120 & 180 \\
\hline 0 & $0.7071 \mathrm{f}$ & $0.9500 \mathrm{e}$ & $1.4370 \mathrm{ab}$ & $1.5490 \mathrm{a}$ \\
0.5 & $0.7499 \mathrm{f}$ & $0.9417 \mathrm{e}$ & $1.2610 \mathrm{~cd}$ & $1.3520 \mathrm{bc}$ \\
1.0 & $0.7478 \mathrm{f}$ & $0.8911 \mathrm{e}$ & $1.1800 \mathrm{~d}$ & $1.1950 \mathrm{~d}$ \\
1.5 & $0.7646 \mathrm{f}$ & $0.9357 \mathrm{e}$ & $1.1660 \mathrm{~d}$ & $1.4590 \mathrm{ab}$ \\
\hline CV $(\%)$ & 6.49 & & \\
\hline
\end{tabular}

In column the common letters are not significantly different from each other at $5 \%$ level of significance by DMRT

\section{Conclusions}

Based on the results of the study it could be concluded that hollow stem disorder in broccoli is favored by higher rate of $\mathrm{N}$ application, while $\mathrm{B}$ application up to $1.0 \mathrm{~kg} \mathrm{ha}^{-1}$ would reduce the incidence of hollow stem without hampering the crop yield. Considering the yield and quality of broccoli, a combined application of $180 \mathrm{~kg} \mathrm{~N}$ with $1.0 \mathrm{~kg} \mathrm{~B} \mathrm{ha}^{-1}$ has been found suitable for achieving higher yield of quality broccoli. Therefore, the combined dose of $180 \mathrm{~kg} \mathrm{~N}$ and $1.0 \mathrm{~kg} \mathrm{~B} / \mathrm{ha}$ could be considered for achieving the maximum yield of quality broccoli in Shallow-Red-Brown Terrace Soil of Madhupur Tract.

\section{References}

Babik, I. and K. Elkner, 1999. The effect of nitrogen and irrigation on yield and quality of broccoli. Workshop towards and ecologically sound fertilization in field vegetable production. ISHA, Acta Horticulture: 571

Bradford, G. R. 1975. Boron, In Chapman, H.D. (Ed.) Diagnostic criteria for plants and soils, Eurasia, Publishing House, New Delhi, India. 38 p.

Default, R.J. 1988. Nitrogen and phosphorus requirements for green house broccoli 
production. Horticultural Science. 23: 576-578.

Erdem, Tolga ArIn, Levent Erdem, Yesim Polat, Serdar Deveci, Murat Okursoy, Hakan Gültas and T. Hüseyin (2010). Yield and quality response of drip irrigated broccoli (Brassica oleracea L. var. italica) under different irrigation regimes, nitrogen applications and cultivation periods. Agricultural Water Management. 97 (5): 681-688.

Hipp, B. W. 1974. Influence of nitrogen and maturity rate on hollow stem in broccoli. Horticultural Science. 9: 68-69.

Lent, J. M. and Scarchuk, J. 1954. Effect of boron on cabbage and cauliflower. University of Connecticut Progress Report-1.

Liu, L., B. J. Shelp, and G. A. Spiers, 1993. Boron distribution and translocation in field-grown broccoli (Brassica oleracea var. italica). Canadian Journal of Plant Science. 73: 587-600.

Mishra, H. P. and B. P. Singh, 1984. Influence of foliar application of nitrogen, boron and Gibberellic acid on the yield contributing characters and yield of cauliflower. Bangladesh Horticulture. 12: 21-25.

Moniruzzaman, M. S. M. L. Rahman, M. G. Kibria, M. A. Rahman And M. M. Hossain, 2007. Effect of boron and nitrogen on yield and hollowstem of broccoli. Journal of. Soil and Nature. 1 (3):24-29

Nasreen, S and M. S. Islam, 1992. Response of cabbage to N. P. K. Zn and Mo fertilization. Bangladesh Journal of Agricultural Science. 19: 231-285.

Sajeemas Pasakdee, Gary Banuelos, Carol Shennan and Weixin Cheng, 2006. Organic $\mathrm{N}$ fertilizers and irrigation influence organic broccoli production in two regions of California. Journal of Vegetable Science. Vol. 12(4): 27-45.
Sanjay, K., D.R. Chawdhury and S. Kumar, 2002. Effect of FYM, molybdenum and boron application on yield attributes and yields of cauliflower. Crop Research. 24: 494-496.

Sartori de Camargo, Mônica and da Costa Mello, Simone, 2009. Nitrogen and boron interactions on hollow stem disorder in cauliflower under tropical conditions: effect of boron, nitrogen and soil. The Proceedings of the International Plant Nutrition Colloquium XVI, Department of Plant Sciences, UC Davis.

Sharma, R.P. and P.N. Arora, 1984. Response of mid-season cauliflower to rates and time of nitrogen application and plant density. Indian Journal of Agronomy. 29: 468470.

Shattuck, V. I., Shelp, B. J., Loughton, A. and Baker, R. 1986. Environmental stbility of yield and hollow stem in broccoli. Canadian Journal of Plant Science. 66:683-688.

Shattuck, V. I. and B. J. Shelp, 1987. Effect of Boron nutrition on hollow stem in Broccoli (Brassica oleracea var. Italica). Canadian Journal of Plant Science. 67:1221-1225.

Shelp, B. J., R. Penner and Z. Zhu. 1992. Broccoli (Brassica oleracea var. Italica) cultivar response to boron deficiency. Canadian Journal of Plant Science. 72: 883-888.

Thompson, H. C. and W. C. Kelly. 1985. Vegetable Crops. $5^{\text {th }}$ edition, Mcgrow-Hill Book Co. 15, 280-281, 370 pp.

Trimblay, N. 1989. Effect of nitrogen sources and rates on yield and hollow stem development in broccoli. Canadian Journal of Plant Science. 69: 1049-1053.

Vigier, B. and Cutcliffe, J. A. 1984. Effect of boron and nitrogen on the incidence of hollow stem of broccoli. Acta horticulture. 157: 303-308. 